\title{
Joaquín Serrano Serrano, Antonio de Valbuena (1844 - 1929) Poeta, narrador y crítico polémico, Universidad de León, 2007, 523 págs.
}

Este libro, que acaba de ser editado por la Universidad de León y prologado por José María Balcells, catedrático de Literatura Española de la misma, pone de relieve dos realidades: una, que hay muchos personajes de la historia, conocidos por la mayoría solo por el nombre (y esto en el mejor de los casos) debido a instituciones, organismos o centros, de un cariz u otro, que lo han tomado como nombre de identidad, pero que son de enorme trascendencia en el ámbito cultural o político por su obra, su pensamiento o su actividad; tal es el caso del escritor objeto de estudio, cuyas obras han caído la mayoría en el olvido o apenas son mencionadas en historias de la literatura y libros de texto, lo cual marca un llamativo contraste con la opinión de un acreditado hispanista francés, Jean-François Botrel, recogida por Joaquín Serrano en nota a pie de página $(377$, p. 459) y que nos parece necesario y conveniente reproducir:

El caso de Valbuena, creador bien pensante y crítico virulento de la lengua legítima, es, en tanto que revelador de tensiones sociales en torno a problemas lingüísticos y estéticos, digno de ser tenido en cuenta para una verdadera historia literaria de España.

La segunda realidad evidenciada por el citado libro es que la labor de investigación siempre resulta gratificante y atractiva cuando el resultado es un producto tan bien elaborado como esta obra que recientemente ha visto la luz.

Para corroborar ambas evidencias, basta con leer el mencionado estudio y descubrir la figura de Antonio de Valbuena en sus múltiples facetas, indicadas en el propio título, así como comprobar el buen hacer de Joaquín para llevar a cabo este amplio y serio trabajo sobre dicho personaje de la historia, sin calificativos, de nuestra España de finales del XIX y principios de XX, como corresponde a su cronología vital.

Por el título, el lector puede pensar que se trata de una biografía al uso de tal género en la que cronológicamente se recorre el devenir personal, privado o público, del biografiado; pero, con la simple observación del índice con el que se abre el estudio y, principalmente, con la lectura del texto completo, se comprueba que no es así y que el trabajo está organizado más por etapas y contenido que por periodos cronológicos, a lo largo de cinco bloques.

El bloque o capítulo I (el autor no lo determina, quizá porque lo menos importante sea el término) es el más extenso, con casi 200 páginas, y aparece ilustrado con 20 fotografías (11 de Pedrosa y 9 del escritor biografiado). Tal vez todo ello sea fruto de la relación que el autor del libro tuvo con Pedrosa del Rey, localidad natal de Antonio de Valbuena, y que, sentimentalmente y en el recuerdo, sigue teniendo. Ello le permitió conocer personas (familiares, amigos y conocidos) y rincones con las huellas del escritor, tal como el mismo Joaquín declara en nota a pie de página (1, p.19). Sólo era necesario que alguien soplase sobre el polvo que los cubría para que saliesen a la luz. Y se ha logrado con esta obra. 
En los bloques siguientes (II, III, IV), de diferente extensión, pero de similar interés, el autor hace un recorrido por la obra de Antonio de Valbuena según los distintos géneros cultivados, -poesía, narrativa y crítica-, sin olvidar sus actividades periodísticas como redactor de El siglo futuro y comentarista en El Imparcial. Por tanto podemos dar por ciertas las palabras de Joaquín Serrano al comienzo de su "Presentación": Este libro pretende dar una visión global de la vida y obra de Antonio de Valbuena, poeta, narrador y polémico crítico leonés.

En el apartado dedicado a la obra narrativa, destacan varios títulos: Agua turbia, novela larga, y cinco libros de relatos entre los que figuran Rebojos y Parábolas.

El más extenso de los tres es el IV, dedicado al estudio de la obra crítica del autor, faceta en la que Antonio de Valbuena destacó por la abundancia y la profundidad de sus comentarios. Debido a su labor crítica y a los títulos dados a sus aportaciones, se le conoce como el "inventor de los ripios"; son destacables Ripios Aristocráticos, Ripios Académicos, Ripios Vulgares, Ripios Ultramarinos o cuatro tomos de Fe de erratas del Diccionario de la Academia. En este sentido destacan las controversias mantenidas con escritores contemporáneos, entre los que cabe citar a Menéndez Pelayo, Emilia Pardo Bazán, Manuel Gutiérrez Nájera, Julio Casares o Julio Cejador; polémicas que le acarreaban fama y que él mismo atizaba.

Es muy destacable que cada poema o poemario, cuento, novela o libro de crítica vaya acompañado de un comentario o resumen de su contenido ya que ello evidencia que el autor de este estudio conoce, de propia lectura, cada una de las obras de este escritor, o por referencias muy directas "de primera mano" y que su dedicación a la enseñanza le ha demostrado que una buena manera de formar al lector es informarle con rigurosidad y claridad pedagógica.

Es un trabajo que viene, por tanto, a llenar el vacío que, a pesar del interés de personas o grupos por el escritor, había generado la inexistencia de una obra de conjunto y esta lo es, tal como se dice en la "Conclusión":

Aquí queda, pues, la visión general de la vida y producción literaria de Antonio de Valbuena, $\tan$ oportuna, $\tan$ necesaria, para conocer los entresijos del desenvolvimiento de nuestra literatura, de nuestra cultura, y para vivir el hervor y hervir de las ideas en los años de la Restauración y el salto del siglo XIX al XX.

Además de presentar una visión general, constituye un acercamiento objetivo y ajeno tanto a los aplausos de los «valbuenistas» como a las censuras de los «antivalbuenistas», predominando el equilibrio, la independencia y la veracidad de lo que sobre el escritor, su familia y su entorno se dice sin apologías ni persecuciones. Esto lo ratifica la inclusión de una serie de documentos al final de la obra, además de apéndices y anexos que implican una tarea de documentación previa a la redacción del estudio. Y no era de esperar otro enfoque dada la forma de trabajar del profesor Serrano Serrano, reflejada en la ya abundante bibliografía que lleva su nombre.

Cualquier lector puede descubrir la minuciosidad en la observación "a pie de obra", el "trabajo de campo", la relación de personas, organismos e instituciones consultadas, referida en el capitulo de Agradecimientos, y que constituye la característica del quehacer de este investigador y trabajador 
incansable, tal como se puede comprobar si nos acercamos a su trabajo Romances vivos en la montaña leonesa (1986).

Para cerrar el libro, el profesor Serrano Serrano, además de la referencia bibliográfica exigida por el código de todo estudioso e investigador, incorpora dos apartados: Anexos y Apéndices, de sumo interés y utilidad, que vienen a apuntalar, por si no había quedado suficientemente demostrado a lo largo de todo el estudio, el método seguido: documentación (es destacable el catálogo que hace de las opiniones que otros escritores han dado de Antonio de Valbuena recogidas en la "Conclusión" y en los Apéndices), minuciosidad y objetividad; de todo ello ha brotado este trabajo intenso y "tan extenso como concienzudo y bien documentado", como dice José María Balcells en el prólogo, además de, sigue diciendo el prologuista,

imprescindible para el conocimiento cabal de uno de los escritores leoneses más singulares, y singular por diversos motivos: en virtud de su peculiarísima personalidad, de lo diverso de su escritura, de la agudeza satírica de su pluma, y de la insólita resonancia de varias de sus críticas.

Se trata, en definitiva, de una obra, no solo valiosa, sino necesaria e imprescindible para conocer a este ilustre y polifacético escritor leonés, "un prosista de los buenos; en su prosa hay sabor castellano", como dice Azorín (Apéndice 6, p. 506), "un crítico terrible”, en opinión de Juan José Soiza Reilly (Apéndice 5, p. 504), "un escritor correcto, fácil, gracioso y franco, [...], y un crítico de gusto delicado" según Clarín (Apéndice 2, p. 497), " ...temible satírico, anarquista y reaccionario en una pieza...", como lo considera el P. Francisco Blanco García (Apéndice 1, p. 493).

Todo el que quiera comprobar esto y mucho más, solo tiene que conocer lo que Joaquín Serrano Serrano ha plasmado magistralmente en Antonio de Valbuena (1844 - 1929).Poeta, narrador y crítico polémico, una visión general, detallada y científica de la personalidad y obra del escritor leonés.

Santiago Pérez Fernández 